\title{
The Ti-Influence on the Tourmaline Color
}

\author{
Warde A. da Fonseca-Zang, ${ }^{*, a}$ Joachim W. Zang ${ }^{a}$ and Wolfgang Hofmeister ${ }^{b}$ \\ ${ }^{a}$ Área de Química, Centro Federal de Educação Tecnológica de Goiás, Rua 75, n. 46, Setor Central, \\ 74055-110 Goiânia-GO, Brazil \\ ${ }^{b}$ Geomaterialwissenschaften, Johannes Gutenberg-Universität Mainz, 55099 Mainz, Germany
}

\begin{abstract}
Titânio em turmalinas pretas foi analisado por espectrofotometria entre 12500 e $27000 \mathrm{~cm}^{-1}$ (800-370 nm) em um microscópio MPV-5P, Leitz (Alemanha), e analisado quimicamente em uma micro-sonda eletrônica Camebax Microbeam, Cameca (France) (WDS-mode). Quatorze turmalinas orientadas com faces paralelas ao eixo trigonal, cortadas e polidas até espessuras finas mostraram, em espectros polarizados, duas bandas largas de absorbância a aproximadamente $14000 \mathrm{~cm}^{-1}(715 \mathrm{~nm})$ e $24000 \mathrm{~cm}^{-1}(417 \mathrm{~nm})$. Medidas de espessura das amostras foram usadas no cálculo de coeficientes de absorção $\alpha\left(\mathrm{cm}^{-1}\right)$. Para a banda em torno de $24000 \mathrm{~cm}^{-1}(417 \mathrm{~nm})$, foi observada uma correlação linear entre $\alpha$ e a concentração em massa de $\mathrm{TiO}_{2}(\%)$. Outra regressão foi observada entre $\alpha$ e o produto da concentração em massa de $\mathrm{TiO}_{2}(\%)$ e $\mathrm{FeO}(\%)$. Cátions localizados em grupos de octaedros $\mathrm{Y}$ e $\mathrm{Z}$ conectados através dos seus lados podem contribuir para as transferências de carga $\mathrm{Ti}^{3+}-\mathrm{Ti}^{4+}, \mathrm{Fe}^{2+}-\mathrm{Ti}^{4+}, \mathrm{Ti}^{3+}-\mathrm{Ti}^{4+}-\mathrm{Fe}^{3+}$.
\end{abstract}

Titanium was examined in different black tourmalines by spectrophotometric analyses in the region between 12500 and $27000 \mathrm{~cm}^{-1}(800-370 \mathrm{~nm})$ using a microscope spectrophotometer MPV5P, Leitz (Germany), and chemically analyzed on an electron microprobe Camebax Microbeam, Cameca (France) in WDS Mode. Fourteen tourmaline samples with their face oriented parallel to the principal axis, cut and polished down to thin sections, showed polarized spectra of two broad absorption bands at approximately $14000 \mathrm{~cm}^{-1}(715 \mathrm{~nm})$ and $24000 \mathrm{~cm}^{-1}(417 \mathrm{~nm})$. Precision thickness measurements were used to calculate the absorption coefficients $\alpha$. For the absorption around $24000 \mathrm{~cm}^{-1}$, a linear correlation was observed between $\alpha$ and the $\mathrm{TiO}_{2}$ content (mass \%). Another linear regression was observed between $\alpha$ and the product of $\mathrm{TiO}_{2}$ and $\mathrm{FeO}(\%)$ contents. Cations located in the $\mathrm{Y}$ - and Z-octahedrons of the structure that are connected over edges might contribute to intervalence charge transfer transitions (IVCT) between $\mathrm{Ti}^{3+}-\mathrm{Ti}^{4+}, \mathrm{Fe}^{2+}-\mathrm{Ti}^{4+}$ and $\mathrm{Ti}^{3+}-\mathrm{Ti}^{4+}-\mathrm{Fe}^{3+}$.

Keywords: titanium, IVCT effect, tourmaline

\section{Introduction}

Standard electron microprobe analysis can determine most of the significant elements in tourmalines, except $\mathrm{Li}$, $\mathrm{O}, \mathrm{H}$ and $\mathrm{B}$. The general formula of the tourmaline group can be described as indicated in the general formula (1):

${ }^{[9]} \mathrm{X}^{[6]} \mathrm{Y}_{3}{ }^{[6]} \mathrm{Z}_{6}(\mathrm{O}, \mathrm{OH})_{3}(\mathrm{OH}, \mathrm{F})\left({ }^{[3]} \mathrm{BO}_{3}\right)_{3}\left[{ }^{[4]} \mathrm{Si}_{6} \mathrm{O}_{18}\right]$

where: $\mathrm{X}=\mathrm{Na}, \mathrm{Ca}, \mathrm{K}, \mathrm{Bi}$, vacancies and others; $\mathrm{Y}=\mathrm{Al}$, $\mathrm{Li}, \mathrm{Mg}, \mathrm{Fe}^{\mathrm{II}}, \mathrm{Fe}^{\mathrm{III}}, \mathrm{Mn}^{\mathrm{II}}, \mathrm{Mn}^{\mathrm{III}}, \mathrm{Cr}, \mathrm{V}, \mathrm{Cu}$ and others; $\mathrm{Z}=$

\footnotetext{
*e-mail: warde@quimica-industrial.com
}

$\mathrm{Al}, \mathrm{Fe}^{\mathrm{III}}, \mathrm{Cr}, \mathrm{V}, \mathrm{Mg}, \mathrm{Fe}^{\mathrm{II}}, \mathrm{Ti}^{\mathrm{IV}}$ and others; $\mathrm{B}=\mathrm{B} ; \mathrm{Si}=\mathrm{Si}$, $\mathrm{Al}$ and $\mathrm{B}$.

Substitutions in tourmaline occur mainly at the octahedral $\mathrm{Y}$ and Z-sites, where $\mathrm{Al}$ is replaced by TM cations, mainly $\mathrm{Fe}^{\mathrm{II}}, \mathrm{Fe}^{\mathrm{III}}, \mathrm{Mn}^{\mathrm{II}}, \mathrm{Mn}^{\mathrm{III}}, \mathrm{Cr}, \mathrm{V}, \mathrm{Cu}$ and $\mathrm{Ti}^{\mathrm{IV}}$. The cation $\mathrm{Ti}^{\mathrm{IV}}$ is located mainly in the octahedral sites. ${ }^{1,2}$ The most common tourmaline end-member components are schorl, dravite, elbaite, buergerite, uvite, liddicoatite, olenite, chromdravite, feruvite, hidroxiferuvite and povondraite. At the nine-folded coordinated X-site in natural species, vacancies up to $0.75 \mathrm{per}$ formula unit (pfu) have been described. ${ }^{3,4}$ In synthesized tourmalines the $\mathrm{X}$-site has been described with up to $1.0 \mathrm{X}$-vacancy pfu. ${ }^{5,6}$ The tetrahedral $\mathrm{Si}$-site in the trigonal $\mathrm{Si}_{6} \mathrm{O}_{12}$-rings is 
assumed to be mainly occupied by $\mathrm{Si}$ and $\mathrm{Al}$, if the number of $\mathrm{Si}$ is under $6.0 \mathrm{pfu}$. A statistical data analysis from 785 tourmalines shows distribution with a maximum of 5.95 (2) Si pfu. ${ }^{2}$ Chemical data from 256 complete analyses of natural tourmalines show a maximum distribution at 2.993 (0.054) B pfu. ${ }^{1}$

The color and pleochroism in tourmalines are caused by the transition metal (TM) ions in the Y- and Z- octahedra of the crystal structure, either as major constituents or trace amounts. ${ }^{7}$ When linear polarized light is transmitted through a trigonal tourmaline sample, cut parallel to the three fold $c$ axis, different spectral absorption profiles may be expected, denoted as perpendicular to $c, \omega\left(\mathrm{E}^{\perp} c\right)$, and as parallel to $c, \varepsilon(\mathrm{E} \| c)$. In general the common cause of color is the light absorption in discrete near ultraviolet visible and near-infrared regions through electronic processes, including crystal field transitions within the individual TM cations, intervalence charge transfer transitions (IVCT) between adjacent TM ions or transitions involving TM ions and surrounding anions. Intervalence charge transfer transitions (IVCT) are photochemical oxidation-reduction effects observed in the ultraviolet region, leading to very intense broad absorption bands with absorption coefficients $\alpha=100-10000 \mathrm{~cm}^{-1}$. A shift of these absorption bands to lower energy regions can be expected when neighboring ions exist in different oxidation states in a crystal structure.

In the tourmaline structure, oxygen atoms frequently occur at the vertices of distorted octahedra and TM cationoxygen distances are not identical within a coordination site. The oxygen ions as coordinating ligands in the octahedra might be substituted by $\mathrm{OH}$ or F. Lower symmetry octahedral environments formed by either distortion of the coordination site or different distribution of the ligands in the octahedra lead to further resolution of the $3 \mathrm{~d}$ orbital energy levels and cause additional electronic configurations of different energies and symmetry. Schoenfliess symbols are assigned to spectroscopic terms, regular octahedrons belong to the point group $\mathrm{O}_{h}$, while tetragonally distorted and trigonally distorted octahedra are represented by $\mathrm{D}_{4 \mathrm{~h}}$ and $\mathrm{C}_{3 \mathrm{v}}$, respectively. In each configuration, the $\mathrm{Z}$ axis is the tetrahedral axis and corresponds to the axis of the elongation or compression of the octahedron.

Curve-resolved spectra yielded two sets of paired bands. ${ }^{8}$ The first set at $14500 \mathrm{~cm}^{-1}$ and $9500 \mathrm{~cm}^{-1}$ is assigned to $\mathrm{Fe}^{\mathrm{II}}$ in the $\mathrm{Z}$ octahedral site. The second set of bands at $13200 \mathrm{~cm}^{-1}$ and $7900 \mathrm{~cm}^{-1}$ is attributed to $\mathrm{Fe}^{\mathrm{II}}$ in the $\mathrm{Y}$ octahedral site. In some black and pink tourmaline crystals, broad and high absorption bands located at $18400 \mathrm{~cm}^{-1}$ and $22700 \mathrm{~cm}^{-1}$ and at $19200 \mathrm{~cm}^{-1}$ have been associated with $\mathrm{Mn}^{\mathrm{II}}$ ions. ${ }^{9}$ The band at $18900 \mathrm{~cm}^{-1}$ is assigned to $\mathrm{Fe}^{\mathrm{III}}-\mathrm{Fe}^{\mathrm{III}}$ intervalence charge transfer effects within the Y- or Z-sites and between adjacent $\mathrm{Y}$ - and Z-sites. ${ }^{10}$

An absorption band at $24100 \mathrm{~cm}^{-1}$ has been explained with $\mathrm{Fe}^{\mathrm{II}}-\mathrm{Ti}^{\mathrm{IV}}$ interactions for green and brown tourmalines with high Fe contents. ${ }^{11,12}$ On Earth, the most stable oxidation states of $\mathrm{Ti}, \mathrm{Fe}$ and $\mathrm{Mn}$ in minerals occurring in near-surface environment are $\mathrm{Ti}^{\mathrm{IV}}, \mathrm{Mn}^{\mathrm{II}}, \mathrm{Mn}^{\mathrm{III}}, \mathrm{Mn}^{\mathrm{IV}}$, $\mathrm{Fe}^{\mathrm{II}}$ and $\mathrm{Fe}^{\mathrm{III}}$. Titanium in oxidation state $\mathrm{Ti}^{\mathrm{III}}$ is observed in lunar minerals and glass phases as well as in synthetic materials. ${ }^{7}$

Spectrophotometric measurements within the energy region between 12500 and $27000 \mathrm{~cm}^{-1}(800-370 \mathrm{~nm})$ were made in this work for evaluating the influence of titanium on the tourmaline color.

\section{Experimental}

For this work 14 samples of macroscopic black tourmalines from the Brazilian State of Minas Gerais and from Namibia were specially prepared as oriented section cuts, involving orientation of the crystals on a polariscope with an adapted conoscope (Schneider, Germany). The section samples were cut mainly parallel to the crystallographic $c$-axis using a diamond steel disc (Eigner, Germany) and polished into thin-sections of millimeters or micrometer thickness, using a copper disc (Eigner, Germany) to reach a sufficient energy transmission to measure the absorption spectra. The sections of the tourmalines were additionally polished with a diamond polishing powder paste on both sides (Saint Petersburg, Russia). The thickness of the sections was measured with a micrometer screw.

The chemical analyses of the 14 samples were carried out on a Cameca Camebax electron microprobe in WDS mode (France). The excitation voltage was $15 \mathrm{kV}$ and the beam current $20 \mathrm{nA}$; the beam was defocused to $10 \mu \mathrm{m}$ scan. The calibration standards were $\mathrm{Si}, \mathrm{K}$ - orthoclase, $\mathrm{Al}$ - corundum, $\mathrm{V}, \mathrm{Cu}$ - pure elements standards, $\mathrm{Cr}$ chromite, $\mathrm{Fe}$ - hematite, $\mathrm{Mn}$ and $\mathrm{Ti}$ - alloy of $\mathrm{Mn}$ and Ti, $\mathrm{Ca}$ - wollastonite, $\mathrm{Na}$ - albite and $\mathrm{F}$ - lithium fluorite. The data was corrected with a modified ZAF procedure (PAP). The contents of $\mathrm{B}_{2} \mathrm{O}_{3}, \mathrm{Li}_{2} \mathrm{O}$ and $\mathrm{H}_{2} \mathrm{O}$ were calculated on the basis of 31 anions $\mathrm{O}^{2-}, \mathrm{OH}^{-}$and $\mathrm{F}^{-}$(results in Table 1).

Tourmalines occur as color zoned crystals; therefore, microscope spectrophotometers were used for the spectral measurements of the small color zoned samples. The highly polished plates or thin sections were placed between a condensing and an objective lens in the microscope spectrophotometer MPV-5P Leitz (Solms, Germany). The spectroscopic measurements were performed between 12500 and $27000 \mathrm{~cm}^{-1}(800-370 \mathrm{~nm})$ at a resolution of $0.1 \mathrm{~nm}$. 
The microscope Leitz MPV-5P is restricted to spectral measurements in this energy region due to its glass optics. About 100 scans were averaged for every measurement. The spectra of most of the samples were taken in one point. The background calibration for the spectral measurements was done with a colorless tourmaline sample 28Nig (chemical composition in Table 1), which had been prepared in the same way as the other samples.

Two spectral profiles may be distinguished in trigonal tourmalines, $\omega\left(\mathrm{E}^{\perp} c\right)$ and $\varepsilon(\mathrm{E} \| c)$, where $\mathrm{E}$ represents the direction of polarization of the electric field vector of the incident light on the plane of the section. Sections cut parallel to the $c$ axis (parallel sections) show optical interference features characteristic of uniaxial crystals and those cut perpendicular to $c$ (called 001 sections) show a centered uniaxial cross (axial spectrum).

On the abscissa of the spectra the energy is represented as wavenumber $\left(\mathrm{cm}^{-1}\right)$. On the ordinate the calculated values of the absorption coefficient $\alpha$ are understood as in equation (1),

$\alpha=\log \left(\mathrm{I}_{0} / \mathrm{I}\right) / \mathrm{d}$

using the sample thickness $\mathrm{d}[\mathrm{cm}]$ beside the intensities of the light before $\left(\mathrm{I}_{0}\right)$ and after passing through the sample (I) for the calculation.?

\section{Curve fitting of the spectra}

The spectroscopic data from the Leitz spectrophotometer was stored as ASCII files. Microcal Origin 6.0 software was applied for plotting and fitting the spectral curves. After the background correction with the absorption spectra of the colorless tourmaline sample $28 \mathrm{Nig}$, each spectrum was normalized to its absorption coefficients $\alpha$. The absorption curves were fitted on the complete measuring range for the underlying multiple Gaussian absorption peaks.

\section{Results and Discussion}

The chemical composition of the analyzed samples (this work) is shown in Table 1, classified after the content of $\mathrm{TiO}_{2}$ (mass \%).

The chemical results presented in Table 1 indicate that there are different species of the tourmaline solidsolution-series represented, ranging from Al- and Li-rich elbaite to Fe-rich schorl. The electron microprobe analyses further point to contents of transition metals $\mathrm{Fe}, \mathrm{Mn}$ and $\mathrm{Ti}$, assumed to be located mainly in the octahedral $\mathrm{Y}$ and $\mathrm{Z}$ sites. All these samples were black or dark colored. The color described in Table 1 is observed only in thin sections. The data shown in Table 1 is classified after increasing the $\mathrm{TiO}_{2}$ mass $\%$ content.

Table 1. Chemical composition of the tourmaline samples classified after increasing $\mathrm{TiO}_{2}$ (mass \%) contents. Electron microprobe analyses, $\mathrm{B}_{2} \mathrm{O}_{3}, \mathrm{Li}_{2} \mathrm{O}$ and $\mathrm{H}_{2} \mathrm{O}$ have been calculated stoichiometrically. Total iron content was calculated as $\mathrm{FeO} . \mathrm{V}_{2} \mathrm{O}_{3}$ and $\mathrm{Cr}_{2} \mathrm{O}_{3}$ were analyzed but no contents above detection limits were observed

\begin{tabular}{lllllllllllllllll}
\hline No. & Sample/color & $\mathrm{SiO}_{2}$ & $\mathrm{TiO}_{2}$ & $\mathrm{~B}_{2} \mathrm{O}_{3}$ & $\mathrm{Al}_{2} \mathrm{O}_{3}$ & $\mathrm{FeO}$ & $\mathrm{MnO}$ & $\mathrm{MgO}$ & $\mathrm{CaO}$ & $\mathrm{Na}_{2} \mathrm{O}$ & $\mathrm{K}_{2} \mathrm{O}$ & $\mathrm{Li}_{2} \mathrm{O}$ & $\mathrm{F}$ & $\mathrm{H}_{2} \mathrm{O}^{+}$ & $\mathrm{O}=\mathrm{F}$ & $\mathrm{SUM}^{2}$ \\
\hline 1 & 28Nig-colorless & 38.18 & 0.00 & 11.10 & 42.62 & 0.18 & 0.47 & 0.00 & 0.39 & 1.85 & 0.02 & 1.70 & 1.50 & 2.63 & 0.63 & 100.00 \\
2 & 48MG-green & 38.07 & 0.01 & 10.84 & 38.36 & 1.99 & 2.36 & 0.04 & 0.38 & 2.25 & 0.00 & 2.60 & 1.98 & 1.94 & 0.83 & 100.00 \\
3 & 26MG-green & 36.50 & 0.02 & 11.13 & 40.15 & 1.57 & 0.52 & 0.00 & 0.39 & 2.10 & 0.05 & 2.60 & 1.04 & 4.37 & 0.44 & 100.00 \\
4 & 55Na-green & 36.66 & 0.03 & 10.65 & 36.84 & 7.11 & 0.63 & 0.09 & 0.15 & 2.42 & 0.02 & 2.00 & 1.26 & 2.67 & 0.53 & 100.00 \\
5 & SD4-light green-blue & 38.02 & 0.03 & 10.55 & 36.91 & 7.67 & 0.37 & 0.08 & 0.06 & 2.71 & 0.05 & 1.06 & 1.41 & 1.68 & 0.59 & 100.00 \\
6 & SD5-light green-blue & 37.24 & 0.03 & 10.55 & 36.79 & 8.36 & 0.58 & 0.04 & 0.07 & 2.57 & 0.03 & 0.90 & 1.46 & 2.01 & 0.62 & 100.00 \\
7 & SD12-green & 37.41 & 0.04 & 10.90 & 42.23 & 1.25 & 0.89 & 0.25 & 0.88 & 2.05 & 0.01 & 1.19 & 0.90 & 2.38 & 0.38 & 100.00 \\
8 & SD3-green & 38.45 & 0.04 & 10.78 & 38.91 & 3.88 & 0.65 & 0.25 & 0.60 & 2.38 & 0.03 & 1.42 & 0.77 & 2.16 & 0.32 & 100.00 \\
9 & SD7-light green & 37.61 & 0.07 & 10.55 & 36.45 & 8.61 & 0.12 & 0.31 & 0.07 & 2.58 & 0.03 & 0.95 & 0.60 & 2.30 & 0.25 & 100.00 \\
10 & SD10-light green core & 38.06 & 0.12 & 10.67 & 37.39 & 6.27 & 0.56 & 0.46 & 0.14 & 2.53 & 0.02 & 1.14 & 0.62 & 2.29 & 0.26 & 100.00 \\
11 & SD14-light brown & 38.55 & 0.31 & 10.65 & 37.52 & 5.60 & 0.56 & 0.56 & 0.15 & 2.59 & 0.00 & 1.17 & 1.07 & 1.74 & 0.45 & 100.00 \\
12 & SD13-light brown & 38.16 & 0.33 & 10.65 & 37.19 & 5.98 & 0.71 & 0.30 & 0.15 & 2.68 & 0.03 & 1.22 & 1.21 & 1.88 & 0.51 & 100.00 \\
13 & SD11-dark brown & 38.27 & 0.44 & 10.62 & 37.39 & 6.13 & 0.67 & 0.37 & 0.12 & 2.64 & 0.03 & 1.05 & 0.86 & 1.75 & 0.36 & 100.00 \\
14 & SD6-dark brown & 37.93 & 0.57 & 10.62 & 37.68 & 6.07 & 0.56 & 0.70 & 0.12 & 2.54 & 0.01 & 0.87 & 0.86 & 1.83 & 0.36 & 100.00 \\
15 & SD8-dark brown & 37.88 & 0.70 & 10.50 & 35.89 & 8.13 & 0.05 & 1.48 & 0.05 & 2.53 & 0.02 & 0.59 & 0.98 & 1.57 & 0.41 & 100.00 \\
\hline
\end{tabular}

* Origin of the Samples: 48MG and 26MG, State of Minas Gerais, Brazil; 55Na and SD-series, Namibia. 


\section{Optical properties}

The optical spectra are described taking into consideration the crystallographic direction of certain absorbed wavelengths under different intensities of the absorption coefficient $(\alpha)$. In this work both polarized spectra $\omega\left(\mathrm{E}^{\perp} c\right)$ and $\varepsilon(\mathrm{E} \| c)$ were taken for most of the samples, except for the thin section samples $55 \mathrm{Na}$ green, SD11, SD13 and SD14, prepared for the $\omega\left(\mathrm{E}^{\perp} c\right)$ spectrum.

In Figures $1 \mathrm{~A}$ and $1 \mathrm{~B}$ the polarized spectra (region $12500-27000 \mathrm{~cm}^{-1}$ ) for fourteen samples are plotted. Two main absorption bands around $14000 \mathrm{~cm}^{-1}(714 \mathrm{~nm})$ and $24000 \mathrm{~cm}^{-1}(417 \mathrm{~nm})$ were observed for all samples. For both spectra the intensity of the $24000 \mathrm{~cm}^{-1}$ band, expressed as absorption coefficient $\alpha$, increases gradually with the $\mathrm{TiO}_{2}$ contents for the samples and the strongest absorption was observed in the dark brown sample SD8 with the highest content of $0.70 \% \mathrm{TiO}_{2}$.
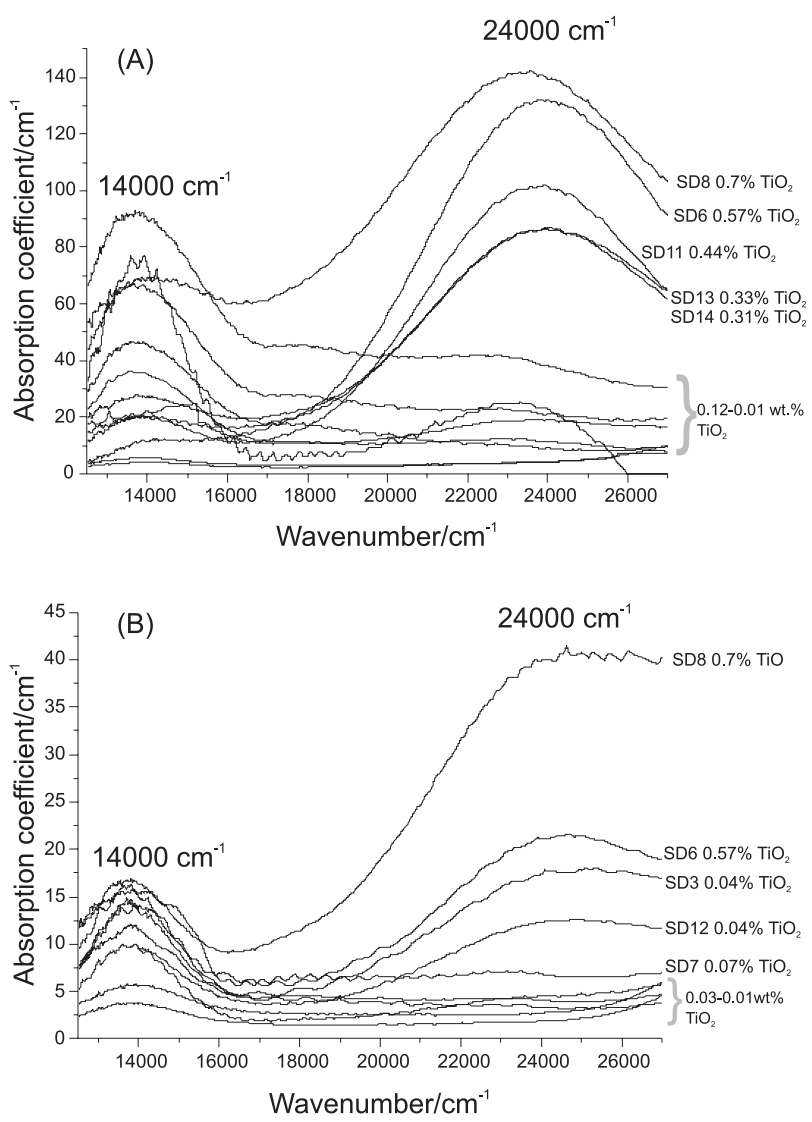

Figure 1. (A) Polarized optical absorption spectra $\mathrm{E}^{\perp} c$ of fourteen tourmaline samples, showing a tendency of correlation of absorption coefficients around $24000 \mathrm{~cm}^{-1}$ with corresponding $\mathrm{TiO}_{2}$ contents. (B) Polarized optical absorption spectra E//c of fourteen tourmaline samples, showing a tendency of correlation between absorption coefficients around $24000 \mathrm{~cm}^{-1}$ with corresponding $\mathrm{TiO}_{2}$ contents.
The spectra of the samples in Figures $1 \mathrm{~A}$ and $1 \mathrm{~B}$ show different absorption intensities of the two bands around $14000 \mathrm{~cm}^{-1}$ and $24000 \mathrm{~cm}^{-1}$. In Figure 1A, for the brown samples SD6, SD8, SD11, SD13 and SD14, a strong dominance of the intensity at $24000 \mathrm{~cm}^{-1}$ was observed; its values exceeded those at $14000 \mathrm{~cm}^{-1}$. In Figure 1B, SD6 and SD8 exhibit brown color for $\mathrm{E} \| c$ and a strong dominance of the intensity at $24000 \mathrm{~cm}^{-1}$ was also observed. For the other samples, the intensities at $24000 \mathrm{~cm}^{-1}$ were similar or smaller than those at $14000 \mathrm{~cm}^{-1}$, causing a green color impression.

The spectra in Figure 1A show, for some samples, an additional absorption band around $18000 \mathrm{~cm}^{-1}$. Absorption bands located at $18400 \mathrm{~cm}^{-1}$ and $22700 \mathrm{~cm}^{-1}$ and at $19200 \mathrm{~cm}^{-1}$ are associated with $\mathrm{Mn}^{\text {III }}$ ions. ${ }^{9}$ At $18900 \mathrm{~cm}^{-1}$ they have been assigned also to $\mathrm{Fe}^{\mathrm{II}}-\mathrm{Fe}^{\mathrm{III}}$ intervalence charge transfer effects within and between the $\mathrm{Y}$ - or Z-sites. ${ }^{10} \mathrm{~A}$ pink tourmaline of Minas Gerais showed a line around $19500 \mathrm{~m}^{-1}$, which after a detailed analysis was also attributed to $\mathrm{Mn}^{\mathrm{III}} .{ }^{14}$ The Tanabe-Sugano diagram shows, for $\mathrm{d}^{5}$ quartet or doublet excited states for $\mathrm{Mn}^{\mathrm{II}}$ in non spin allowed transitions, two large, weak absorption bands around $v_{1}=17000 \mathrm{~cm}^{-1}$, attributed to ${ }^{6} \mathrm{~A}_{1 \mathrm{~g}} \rightarrow{ }^{4} \mathrm{~T}_{1 \mathrm{~g}}$, and $v_{2}=22500 \mathrm{~cm}^{-1}$ to ${ }^{6} \mathrm{~A}_{1 \mathrm{~g}} \rightarrow{ }^{4} \mathrm{~T}_{2 \mathrm{~g}}$, and a very thin peak at $v_{3}=24.088 \mathrm{~cm}^{-1}$, attributed to ${ }^{6} \mathrm{~A}_{1 \mathrm{~g}} \rightarrow{ }^{4} \mathrm{~A}_{1 \mathrm{~g}},{ }^{4} \mathrm{~T}_{\mathrm{Eg}} \cdot{ }^{7}$ The weak absorption bands at $22500 \mathrm{~cm}^{-1}$ and at $24088 \mathrm{~cm}^{-1}$, associated to $\mathrm{Mn}^{\mathrm{II}}$, might be covered by the high absorption around $24000 \mathrm{~cm}^{-1}$.

The crystallographic absorption dependence for the spectra $\omega\left(\mathrm{E}^{\perp} c\right)$ and $\varepsilon(\mathrm{E} \| c)$ is possibly caused by the lower symmetry of the octahedral sites. For the Y octahedron a coordination of 5+1 anions is expected, i.e. five atoms show similar Me-O distance and one is significantly different, where the $\mathrm{Y}_{-} \mathrm{O}_{(3)}$ distance is elongated and $\mathrm{O}_{(3)}$ may be $\mathrm{OH}$ or $\mathrm{O}$. Since the ligand $\mathrm{O}_{(3)}$ is coordinated by the $\mathrm{Y}$ and $\mathrm{Z}$ sites and an elongation of $\mathrm{Z}$ tetrahedral axis of the sites results in the lower symmetry $\mathrm{D}_{4 \mathrm{~h}}$, the occurrence of TM cations in the Y-sites could lead to crystallographic dependencies of absorption spectra in polarized light.

\section{The band around $14000 \mathrm{~cm}^{-1}$}

In crystal field spectra of most $\mathrm{Fe}^{\mathrm{II}}$-bearing minerals, where the $\mathrm{Fe}^{\mathrm{II}}$ is situated in distorted octahedra, two or more separated peaks are generally observed, due to the resolution of the ${ }^{5} \mathrm{~T}_{2 \mathrm{~g}}$ and ${ }^{5} \mathrm{E}_{\mathrm{g}}$ crystal field states into additional levels. The splitting of upper-level $\mathrm{e}_{\mathrm{g}}$ orbital might be obtained from the spectra. Two sets of paired bands could be expected for $\mathrm{Fe}^{\mathrm{II}}$ in the $\mathrm{Y}$ and $\mathrm{Z}$ sites of the tourmaline. One set is located at $14500 \mathrm{~cm}^{-1}$ and 9500 $\mathrm{cm}^{-1}$ for $\mathrm{Fe}^{\mathrm{II}}$ in the Z-site (point group $\mathrm{C}_{1}$; mean distance 
$\mathrm{Al}-\mathrm{O}=192.9 \mathrm{pm}$ ) and the second set of bands is located at $13200 \mathrm{~cm}^{-1}$ and $7900 \mathrm{~cm}^{-1}$, which is attributed to $\mathrm{Fe}^{\mathrm{II}}$ in the Y-site (point group $\mathrm{C}_{\mathrm{m}}$; mean distance $\mathrm{Fe}-\mathrm{O}=202.5 \mathrm{pm}$ ). ${ }^{8}$

Results of this work within the energy region between 12500 and $27000 \mathrm{~cm}^{-1}$ show an absorption band at 14000 $\mathrm{cm}^{-1}$ for the analyzed samples of the two spectrum profiles distinguished in trigonal tourmaline $\omega\left(\mathrm{E}^{\perp} c\right)$ and $\varepsilon(\mathrm{E} \| c)$. Spin-allowed crystal field (CF) transitions within individual cations $\mathrm{Fe}^{\mathrm{II}}$ located mainly in the Y-site should contribute to absorption in lower regions than those with $\mathrm{Fe}^{\mathrm{II}}$ located in the Z-site. The observed band around $14000 \mathrm{~cm}^{-1}$ is located between the expected positions at $13200 \mathrm{~cm}^{-1}$ for the Y-site and at $14500 \mathrm{~cm}^{-1}$ for the Z-site. ${ }^{8} \mathrm{Fe}^{\mathrm{II}}$ ions may be located in two different octahedral sites of the tourmaline structure. Intensification mechanisms assigned to charge transfer between $\mathrm{Fe}^{\mathrm{II}}-\mathrm{Fe}^{\mathrm{III}}$ in $\mathrm{Y}$ - and $\mathrm{Z}$-sites might be considered as well.

\section{The band around $24000 \mathrm{~cm}^{-1}$}

The observed broad band at $24000 \mathrm{~cm}^{-1}$ was investigated in more detail in this work, since this absorption has been related earlier to the $\mathrm{Fe}^{\mathrm{II}}-\mathrm{Ti}^{\mathrm{IV}}$ IVCT interactions located in edge-shared Y- and Z-sites. ${ }^{11,12}$

Within the (001) plane, the $\mathrm{Y}$ and Z-sites are edge connected over the common $\mathrm{O}_{(3)}-\mathrm{O}_{(6)}$ octahedral border. The Y-sites form a brucite like unit of $\mathrm{O}_{(1)}-\mathrm{O}_{(2)}$ edge-shared octahedra. ${ }^{1,2}$ The observed intensity for the broad absorption band at around $24000 \mathrm{~cm}^{-1}$ was initially associated in this work with the $\mathrm{TiO}_{2}$ contents of the analyzed samples (see Table 2 and Figure 1). Considering that the polarized spectrum $\omega\left(\mathrm{E}^{\perp} c\right)$ might result from interactions of the

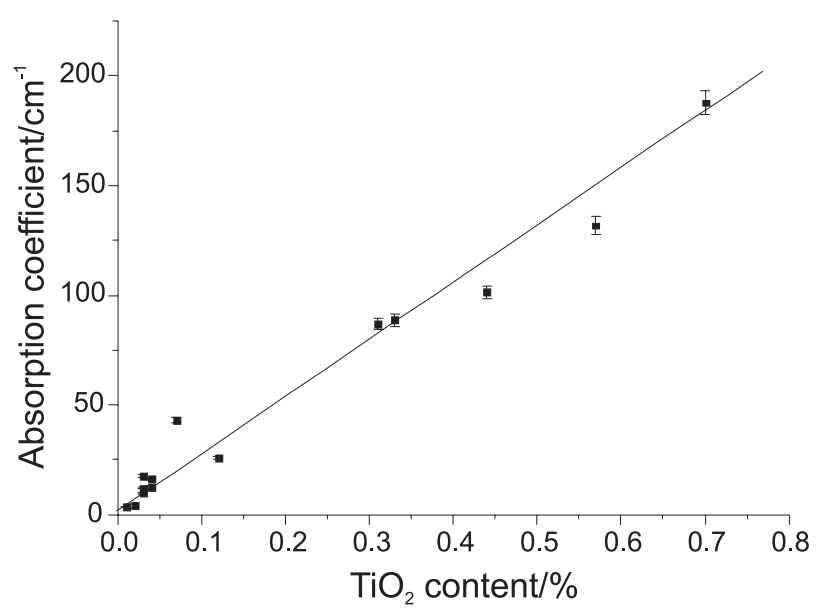

Figure 2. Correlation between $\mathrm{TiO}_{2}$ content (mass $\%$ ) and the observed absorption coefficient $\alpha\left(\mathrm{cm}^{-1}\right)$ for $\mathrm{E}^{\perp} c$ at around $24000 \mathrm{~cm}^{-1}$ for fourteen tourmaline samples.

Linear regression: $\mathrm{Y}=1.76(0.90)+260.84(25.08) \mathrm{X}$ with $\mathrm{R}=0.9487$ (0.0001). electric vector of the incident light within the (001) plane, electron transfer transitions might occur between adjacent cations of titanium with different oxidation states in the octahedral sites, leading to an intense absorption band in spectrum. ${ }^{13}$

Revisions of single crystal structure data from 23 tourmalines show a tendency of increasing Y-Y distances between the cations in the $\mathrm{Y}$ octahedral cluster, compared to $\mathrm{Y}-\mathrm{Z}$ distances of the edge connected octahedral sites for the solid solution series from elbaite (Al tourmaline) to dravite-uvite (Mg tourmaline). ${ }^{2}$ The chemical data of the analyzed samples (Table 1) show species of elbaite and elbaite-schorl, and consequently interactions between $\mathrm{Y}$ cations are more favorable and may contribute to lower charge transfer energies than those between cations in $\mathrm{Y}$ and Z-sites.

The bandwidth at $24000 \mathrm{~cm}^{-1}$ in the spectra $\omega\left(\mathrm{E}^{\perp} c\right)$ is approximately two times larger than that of the band at $14000 \mathrm{~cm}^{-1}$. Large widths at half peak-height are considered to be a diagnostic property of IVCT transitions between two ions in adjacent edged shared octahedra. ${ }^{7}$

Further statistical analyses using chemical and spectrophotometric data

The cations in $\mathrm{Y}$ and $\mathrm{Z}$ sites may influence the observed absorption values $(\alpha)$ at $24000 \mathrm{~cm}^{-1}$. The chemical data for the fourteen samples and the absorption coefficients in Table 1 were used for the correlation in Figure 2.

A correlation of the contents of $\mathrm{TiO}_{2}$ (in mass percent) with the absorption coefficient is shown in Figure 2. A correlation between the absorption coefficient and the

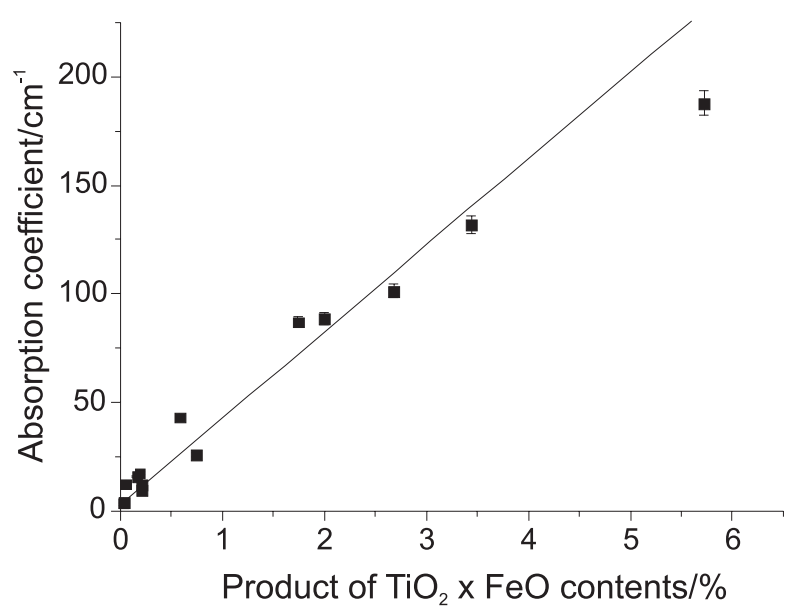

Figure 3. Correlation between the product of $\mathrm{FeO}$ and $\mathrm{TiO}_{2}$ contents (mass\%) and the observed absorption coefficient $\alpha\left(\mathrm{cm}^{-1}\right)$ at around $24000 \mathrm{~cm}^{-1}$ for the tourmaline samples.

Linear regression: $\mathrm{Y}=3.35(0.79)+39.72(4.49) \mathrm{X}$ with $\mathrm{R}=0.9311$ (0.0001). 
Table 2. Values of the absorbance coefficients at about $24000 \mathrm{~cm}^{-1}$ found in polarized spectra $\mathrm{E}^{\perp} c$ with the contents (mass $\%$ ) of $\mathrm{FeO}, \mathrm{TiO}_{2}, \mathrm{MnO}$. Values assigned after increasing $\mathrm{TiO}_{2}$ contents

\begin{tabular}{|c|c|c|c|c|c|}
\hline Sample* & $\begin{array}{l}\mathrm{TiO}_{2} \text { content } \\
(\text { mass } \%)\end{array}$ & $\begin{array}{l}\mathrm{FeO} \text { content } \\
(\text { mass } \%)\end{array}$ & $\begin{array}{l}\mathrm{MnO} \text { content } \\
(\text { mass } \%)\end{array}$ & $\begin{array}{l}\text { Product of } \mathrm{FeO} \cdot \mathrm{TiO}_{2} \\
\text { contents (mass \%) }\end{array}$ & $\begin{array}{l}\text { Abs. Coefficient at about } \\
\quad 24000 \mathrm{~cm}^{-1}\left(\mathrm{E}^{\perp} c\right)\end{array}$ \\
\hline $48 \mathrm{MG}$ & 0.01 & 1.99 & 2.36 & 0.02 & 3.60 \\
\hline 26MG-green & 0.02 & 1.57 & 0.52 & 0.03 & 4.00 \\
\hline $55 \mathrm{Na}$-green & 0.03 & 7.11 & 0.63 & 0.21 & 12.10 \\
\hline SD4-light green-blue & 0.03 & 7.67 & 0.37 & 0.19 & 17.50 \\
\hline SD5-light green-blue & 0.03 & 8.36 & 0.58 & 0.21 & 9.70 \\
\hline SD12-green & 0.04 & 1.25 & 0.89 & 0.05 & 12.50 \\
\hline SD3-green & 0.04 & 3.88 & 0.65 & 0.16 & 16.00 \\
\hline SD7-light green & 0.07 & 8.61 & 0.12 & 0.58 & 43.20 \\
\hline SD10-light green core & 0.12 & 6.27 & 0.56 & 0.74 & 26.00 \\
\hline SD14-light brown & 0.31 & 5.60 & 0.56 & 1.74 & 87.00 \\
\hline SD13-light brown & 0.33 & 5.98 & 0.71 & 2.00 & 88.60 \\
\hline SD11-dark brown & 0.44 & 6.13 & 0.67 & 2.68 & 101.30 \\
\hline SD6-dark brown & 0.57 & 6.07 & 0.56 & 3.44 & 131.80 \\
\hline SD8-dark brown & 0.70 & 8.13 & 0.05 & 5.72 & 187.80 \\
\hline
\end{tabular}

product of the oxide content $(\%)$ of the probable IVCT between $\mathrm{Fe}$ and $\mathrm{Ti}$ is presented in Figure 3. The data of the intensities at around $24000 \mathrm{~cm}^{-1}$ used in the correlations in Figure 2 and Figure 3 are shown in Table 2.

The intensity of spin-allowed IVCT transitions depends more on the populations of the cation pairs in adjacent sites rather than on concentrations of individual cations, considering the error in the absorption intensities (3\%). ${ }^{15}$ The correlation illustrated in Figure 2 with $\mathrm{R}=0.9487$ (0.0001) shows a direct influence of the content of $\mathrm{TiO}_{2}$ in mass percent on the intensity of the band around 24000 $\mathrm{cm}^{-1}$. The linear function (Figure 2) $\mathrm{Y}=1.76(0.90)+$ 260.84 (25.08)X leads to very weak absorption for a null concentration of $\mathrm{TiO}_{2}$.

No direct correlations between the content of $\mathrm{FeO}$ alone (without $\mathrm{TiO}_{2}$ ) and the absorption coefficient were found. After this data a possible indication for two groups of green and green-brown tourmalines was observed.

A similar regression was observed in Figure 3 as $Y=3.35$ $(0.79)+39.72(4.49) \mathrm{X}$ with $\mathrm{R}=0.9311(0.0001)$, and that demonstrates an influence of Ti and $\mathrm{Fe}$, represented through $\mathrm{TiO}_{2} \times \mathrm{FeO}$ (mass \%) contents, on the intensity of the band at $24000 \mathrm{~cm}^{-1}$. These results point to possible interactions in the $\mathrm{Y}$ and $\mathrm{Z}$ octahedral sites between Ti-cations as $\mathrm{Ti}^{\mathrm{III}}-\mathrm{Ti}^{\mathrm{IV}}$ or between $\mathrm{Fe}$ and $\mathrm{Ti}$ cations as $\mathrm{Fe}^{\mathrm{II}}-\mathrm{Ti}^{\mathrm{IV}}$ or $\mathrm{Ti}^{\mathrm{III}}-\mathrm{Ti}^{{ }^{\mathrm{IV}}}-\mathrm{Fe}^{\mathrm{III}}$.

To check a possible influence of $\mathrm{Mn}$ on the band at $24000 \mathrm{~cm}^{-1}$, a similar correlation was applied. A relation with $\mathrm{R}=0.62(0.02)$ was found for the product of the contents on $\mathrm{TiO}_{2} \cdot \mathrm{FeO} \cdot \mathrm{MnO}(\%)$.

\section{Conclusions}

Two broad absorption maxima around $14000 \mathrm{~cm}^{-1}$ (714 nm) and $24000 \mathrm{~cm}^{-1}(416 \mathrm{~nm})$ were observed in all analyzed tourmaline samples. Brown color is observed when the absorption at about $24000 \mathrm{~cm}^{-1}$ becomes much more intense than the other band at around $14000 \mathrm{~cm}^{-1}$. Blue colors are the result of only one principal absorption band at around $14000 \mathrm{~cm}^{-1}$. Green color is associated with both absorption bands.

Titanium contents would compromise the blue and green colors due to the intensification of the absorption band at around $24000 \mathrm{~cm}^{-1}$.

Statistical analyses point to the direct correlation of the $\mathrm{TiO}_{2}$ contents with the absorption coefficients at $24000 \mathrm{~cm}^{-1}$ (regression coefficient $\mathrm{R}=0.9487$ (0.0001)). Another regression shows that the product of the $\mathrm{TiO}_{2}$ and $\mathrm{FeO}$ contents influences the absorption coefficients of this band with $\mathrm{R}=0.9311$ (0.0001). No direct correlation between $\mathrm{MnO}$ contents and the absorption coefficient at $24000 \mathrm{~cm}^{-1}$ was observed. The $\mathrm{Ti}$ and $\mathrm{Fe}$ cations are assigned to $\mathrm{Y}$-octahedral clusters $\left(\mathrm{Y}_{3}\right)$. The $\mathrm{Z}$-octahedrons $\left(\mathrm{Z}_{6}\right)$ may be occupied by $\mathrm{Ti}^{\mathrm{IV}}$ ions and also $\mathrm{Fe}$ cations in minor contents. Both edge connected octahedral sites ( $\mathrm{Y}$ and $\mathrm{Z}$ ) could contribute to the electronic transitions between Ti cations alone or between Ti and Fe. The IVCT-transitions might be described as $\mathrm{Ti}^{\mathrm{III}}-\mathrm{Ti}^{\mathrm{IV}}$ and $\mathrm{Fe}^{\mathrm{II}}-\mathrm{Ti}^{\mathrm{IV}}$ or $\mathrm{Ti}^{\mathrm{III}}-\mathrm{Ti}^{\mathrm{IV}}-\mathrm{Fe}^{\mathrm{III}}$, causing absorbance at around $24000 \mathrm{~cm}^{-1}$. 


\section{Acknowledgments}

The authors are indebted to the National Councel of Technological and Scientific Developmnet, CNPq (Conselho Nacional de Desenvolvimento Científico e Tecnológico).

Our special thanks are dedicated to the referees of this article, who contributed with valuable suggestions to improve the quality of the present work.

\section{References}

1. Zang, J. W.; PhD Thesis, Fachbereich Geowissenschaften, Universität Mainz, Germany, 1994.

2. da Fonseca, W. A. B.; PhD Thesis, Fachbereich Geowissenschaften, Universität Mainz, Germany, 1997.

3. Macdonald, D. J.; Hawthorne, F. C.; Grice, J. D.; Am. Mineral. 1993, 78, 1299.

4. Selvay, J. B.; Novak, M.; Hawthorne, F. C.; Černý, P.; Ottoloni, L.; Kyser, T. K.; Am. Mineral. 1998, 83, 896.
5. Kahlenberg, V.; Veličkov, B.; Eur. J. Mineral. 2000, 12, 947.

6. Wodara, U.; Schreyer, W.; Eur. J. Mineral. 2001, 13, 521.

7. Burns, G. R.; Mineralogical Applications of Crystal Field Theory, $2^{\text {nd }}$ ed., University Press: Cambridge, 1993.

8. Faye, G. H.; Manning; P. G.; Gosselin, J. R.; Tremblay, R. J.; Can. Mineral. 1974, 12, 370.

9. Manning, P. G.; Can. Mineral. 1973, 11, 971.

10. Faye, G. H.; Manning, P. G.; Nickel, E. H.; Am. Mineral. 1968, $53,1174$.

11. Rossman, G. R.; Mattson, S. M.; Am. Mineral. 1986, 71, 599.

12. Mattson, S. M.; Rossman, G. R.; Phys. Chem. Miner. 1988, 16, 78.

13. Loeffer, B. M; Burns, R. G.; Tossel, J. A.; Geochim. Cosmochim. Acta Suppl. 1975, 6, 2663.

14. Camargo, M. B.; Isotani, S.; Am. Mineral. 1988, 73, 172.

15. Isotani, S.; Watari, K.; Mizukami, A.; Bonventi Junior, W.; Ito, A. S.; Phys. B 2006, 391, 322.

Received: October 25, 2007

Web Release Date: July 25, 2008 